\title{
Growth response of the submerged macrophyte Myriophyllum spicatum to sediment nutrient levels and water-level fluctuations
}

\author{
Jia-Jie Cao', Ying Wang' ${ }^{2}$ Zun-Ling Zhu',** \\ ${ }^{1}$ College of Landscape Architecture, Nanjing Forestry University, Nanjing 210037, PR China \\ ${ }^{2}$ Nanjing Institute of Geography \& Limnology, Chinese Academy of Sciences, Nanjing 210008, PR China
}

\begin{abstract}
Sediment nutrient levels and water-level fluctuations are important factors that affect the development and growth of submerged macrophytes; however, little is known about the adaptive responses of macrophytes to these factors. We conducted an experiment using the submerged macrophyte Myriophyllum spicatum L. grown under 2 sediment nutrient levels (high: $2.7 \mathrm{mg} \mathrm{g}^{-1}$ total nitrogen, TN; $1.5 \mathrm{mg} \mathrm{g}^{-1}$ total phosphorus, TP; low: $1.45 \mathrm{mg} \mathrm{g}^{-1} \mathrm{TN}$ and $0.70 \mathrm{mg} \mathrm{g}^{-1} \mathrm{TP}$ ) and 3 amplitudes of water-level fluctuation (static, $\pm 50 \mathrm{~cm}, \pm 100 \mathrm{~cm}$ ) in outdoor ponds. We hypothesized that increased nutrient supply would promote the growth of $M$. spicatum, which can acclimate to the negative effects of moderate water-level fluctuations. After $112 \mathrm{~d}$ of growth under high-nutrient conditions, the plants produced a greater shoot biomass (higher branch number and length), resulting in greater accumulation of total biomass. However, plant growth was inhibited by increasing the amplitude of the water-level fluctuations: at $\pm 100 \mathrm{~cm}$, the plants allocated more biomass to the roots and produced fewer and longer branches. Conversely, plant growth was promoted in the high-nutrient sediments at $\pm 50 \mathrm{~cm}$ amplitude. The production of auto-fragments was increased in the high-nutrient sediment but was significantly decreased by high water-level fluctuations. Thus, sediment nutrient levels and water-level fluctuations have strong interactive effects on the growth and reproduction of $M$. spicatum, and increased sediment nutrients in combination with moderate water level fluctuations facilitate nutrient acquisition, plant growth, and reproduction. Our study implies that moderate water-level fluctuations benefit the restoration of submerged macrophyte communities, particularly in high-nutrient habitats.
\end{abstract}

KEY WORDS: Auto-fragmentation $\cdot$ Myriophyllum spicatum $\cdot$ Submerged macrophyte $\cdot$ Sediment nutrients $\cdot$ Water-level fluctuations

\section{INTRODUCTION}

Sediment nutrients and water-level fluctuations are important factors that affect the development of submerged macrophytes in shallow lakes (Xie et al. 2009, Yu \& Yu 2009). Sediment is the primary source from which most submerged macrophytes take up macro- and microelements (Barko \& Smart 1983, Barko et al. 1986, Barko \& Smart 1986), although submerged macrophytes can take up nutrient ions from the water column in some eutrophic cases (Madsen \&
Cedergreen 2002). The effect of sediment nutrients on the growth of submerged macrophytes has received increasing attention during the past decade (Smith et al. 2002, Hangelbroek et al. 2003, Xiao et al. 2006, Wang \& Yu 2007). Variations in the response of plants to sediment nutrient levels have been reported for plant size (Xie \& Yu 2011a), biomass and resource allocation (Xie et al. 2004), plastic adjustments (Mony et al. 2007), root structure (Xie et al. 2007), and reproductive strategy (Xiao et al. 2006). Even small variations in nutrient availability can 
cuase large differences in plant growth and morphological responses (Sugiyama \& Bazzaz 1998, Müller et al. 2000). If mineral elements are scarce, terrestrial plants often allocate a greater proportion of their biomass to the root system, which increases the root:shoot biomass ratio (Hermans et al. 2006). However, most previous studies in aquatic habitats regarding such morphological changes only focused on single factors (e.g. nutrient availability), whereas evidence for morphological changes in response to multiple factors is lacking.

Water-level fluctuation is a component of the hydrological regime defined by the water depth and duration, frequency, amplitude, and timing of flooding and desiccation events (Yu \& Yu 2009). Natural water-level fluctuation is a dynamic process that affects submerged macrophytes both temporally and spatially (Coops et al. 2003, Yu \& Yu 2009). For example, an extremely high water level during the growing season may reduce the production of submerged macrophytes by limiting light availability, whereas a low water level during the summer may damage plants through wave action or desiccation (Coops et al. 2003, Bornette \& Puijalon 2011). Submerged macrophytes generally respond to high fluctuations in the water level through morphological adaptations, such as stem/leaf elongation and aboveground biomass allocation (Strand \& Weisner 2001, Pilon \& Santamaría 2002, Yang et al. 2004, Yu \& Yu 2009, Huber et al. 2012). Many studies have focused primarily on the water depth gradient (i.e. simply comparing different water depths), but few experimental studies have addressed the role of water level fluctuation on the growth of submerged macrophytes (Deegan et al. 2007, Yu \& Yu 2009, Zhang et al. 2012).

Several recent studies have also demonstrated that an increased nutrient supply can mitigate the negative effects of flooding (i.e. fluctuating water levels) on the growth of fast-growing wetland species and floating leaved species (Xie et al. 2009, Yu \& Yu 2011), suggesting interactions between nutrient availability and water-level fluctuations. Indeed, in flooded environments, nutrient absorption is generally reduced due to inactive root activity and an insufficient energy supply (Jackson \& Drew 1984). However, if a high nutrient supply is also available, plants might gain constructive material for root growth and stem/petiole elongation to address flooding stress (e.g. turbidity and anoxia; Xie et al. 2009, Deegan et al. 2012). In addition, high nutrient levels may also reduce or even reverse the effect of flow velocity on plant biomass and leaflet number per leaf of wetland species (Puijalon et al. 2007). High levels of nutrients can promote shoot production (Xie \& Yu 2011a,b) and might increase the tensile strength of rooted submerged macrophytes (Brewer \& Parker 1990), which could help the plants resist the physical effects of waves at low water levels. Nevertheless, our understanding of the mechanisms by which the growth of submerged macrophytes is affected by the interaction between nutrient availability and waterlevel fluctuations remains limited.

Myriophyllum spicatum L. is a perennial submerged aquatic macrophyte native to Europe and Asia and is dominant in freshwater regions throughout China (Cook 1990, Xie et al. 2007, Xie \& Yu 2011a). This species is considered to be among the most troublesome aquatic weed species worldwide and has been shown to form thick monospecific stands that reduce the relative abundance and richness of other species in North America and North Africa (Grace \& Wetzel 1978, Aiken et al. 1979, Buchan \& Padilla 2000, Smith et al. 2002, Ali \& Soltan 2006). The dispersal and population expansion of $M$. spicatum occurs mainly via auto-fragments, i.e. selfformed stem segments (Smith \& Barko 1990, Smith et al. 2002), which are able to spread across very long distances and colonize new habitats (Smith \& Barko 1990, Santamaría 2002). M. spicatum occurs in various sediment types and can tolerate low-light environments, such as extra-eutrophic waters (Barko \& Smart 1983, Smith \& Barko 1990). This species is therefore widely used for eutrophic lake restoration in China (Qiu et al. 2001, Gao et al. 2007).

We studied the effects of different sediment nutrient levels and water-level fluctuations on the growth of Myriophyllum spicatum. Two hypotheses were tested: (1) M. spicatum can adapt to changing sediment nutrient levels and water-level fluctuations via morphological plasticity; and (2) high sediment nutrient levels and moderate water-level fluctuations promote plant growth and auto-fragment production, whereas low sediment nutrient levels and high waterlevel fluctuations significantly inhibit plant growth and auto-fragment production.

\section{MATERIALS AND METHODS}

\section{Plant material}

The study was conducted at an experimental garden $2 \mathrm{~km}$ from Taihu Lake $\left(31^{\circ} 30^{\prime} \mathrm{N}, 120^{\circ} 30^{\prime} \mathrm{E}\right)$ in Yixin City, Jiangsu Province, China. In mid-March 2011, 200 apical shoots (7 cm long) of Myriophyllum 
spicatum were collected from Taihu Lake (sediment total nitrogen, TN: $1.33 \mathrm{mg} \mathrm{g}^{-1}$ and total phosphorus, TP: $0.75 \mathrm{mg} \mathrm{g}^{-1}$ ). The shoots were transplanted into containers filled with clean sand (obtained from the Yangtze River) and $20 \mathrm{~cm}$ of lake water (mean $\pm \mathrm{SE}$ TN: $2.58 \pm 0.67 \mathrm{mg} \mathrm{l}^{-1}$; TP: $0.10 \pm 0.01 \mathrm{mg} \mathrm{l}^{-1}$ ) in a greenhouse (mean \pm SE water temperature: $24.53 \pm$ $2.23^{\circ} \mathrm{C}_{\text {in }}$ in situ irradiance: $1780 \pm 36.32 \mu \mathrm{mol}$ photons $\mathrm{m}^{-2} \mathrm{~s}^{-1}$ ) for approximately $2 \mathrm{wk}$ until the plants displayed well-developed root systems.

\section{Experimental design}

After the plants developed roots, 48 apical shoots of similar initial biomass and shoot length $(0.81 \pm 0.03 \mathrm{~g}$ wet weight and $17.18 \pm 0.44 \mathrm{~cm}$, mean $\pm \mathrm{SE}$ ) were planted in 48 plastic pots $(20 \mathrm{~cm}$ diameter, $15 \mathrm{~cm}$ in height) filled with approximately $15 \mathrm{~cm}$ of Taihu Lake substratum. Six pots with different treatments were randomly suspended at different positions in 1 of 8 outdoor concrete ponds $\left(3.0 \times 3.0 \times 2.5 \mathrm{~m}_{i}\right.$ the pots were separated by thin nylon fishing net) and filled with fresh lake water (mean \pm SE TN: $2.88 \pm$ $0.77 \mathrm{mg} \mathrm{l}^{-1}$, TP: $0.12 \pm 0.02 \mathrm{mg} \mathrm{l}^{-1}$; to minimize the influence of phytoplankton, the water was filtered using a plankton net). The pots were individually adjustable in the vertical direction by ropes connected to steel bars lying on top of the ponds. Two nutrient sediments were tested: a high-nutrient sediment $(6 \mathrm{~kg}$ pure clay substratum mixed with $50 \mathrm{~g}$ of smart-release fertilizer Osmocote ${ }^{\circledR}$ ) with $2.70 \mathrm{mg} \mathrm{g}^{-1}$ $\mathrm{TN}$ and $1.50 \mathrm{mg} \mathrm{g}^{-1} \mathrm{TP}$ and a low-nutrient sediment ( $6 \mathrm{~kg}$ of pure clay substratum) with $1.45 \mathrm{mg} \mathrm{g}^{-1} \mathrm{TN}$ and $0.70 \mathrm{mg} \mathrm{g}^{-1} \mathrm{TP}$. The substrata were obtained from Taihu Lake, and the TN and TP concentrations in the high-nutrient treatment approximated those occurring in eutrophic sediments in Taihu Lake (Chen et al. 2011). For each sediment nutrient treatment, 3 amplitudes of water-level fluctuations were tested over 8 cycles during $112 \mathrm{~d}\left(14 \mathrm{~d} \mathrm{cycle}^{-1}\right)$ based on historical monthly water-level fluctuation data for Taihu Lake: static $(120 \mathrm{~cm}$ depth) $\pm 50 \mathrm{~cm}$ (from 2000 to 2010), and $\pm 100 \mathrm{~cm}$ (from 1989 to 1999). These amplitudes corresponded to flooding (draw-down) rates of 0,7 , and $14 \mathrm{~cm} \mathrm{~d}^{-1}$. Each treatment was replicated 8 times. The light intensities at 4 depths (water surface, 120,170, and $220 \mathrm{~cm}$ ) in the water column were recorded at noon every day (mean \pm SE irradiance values at the water surface and at depths of 120,170 , and $220 \mathrm{~cm}$ were $1361 \pm 27.18,167 \pm 11.22$, $98 \pm 7.06$, and $45 \pm 5.13 \mu \mathrm{mol}$ photons $\mathrm{m}^{-2} \mathrm{~s}^{-1}$, respectively).
The study was conducted in 2011 during the active growth period of Myriophyllum spicatum in Taihu Lake, from 29 April to 7 July. During the experiment, auto-fragments were dried at $80^{\circ} \mathrm{C}$ for $48 \mathrm{~h}$ and weighed when they were abscised from the parental plants each day. At the end of the experiment, the individual plants were harvested and categorized into roots, above-ground tissues, and auto-fragments, and the stem lengths were measured. Dry weights of the various parts of the plants were measured after drying at $80^{\circ} \mathrm{C}$ for $48 \mathrm{~h}$.

\section{Statistical analysis}

All data were transformed using the $\log (x+1)$ function to ensure homoscedasticity and normality of the residuals. Effects of the sediment nutrient level and amplitude of water-level fluctuations on branch number, branch length, shoot length, and autofragment biomass were tested with 2-way analysis of covariance (ANCOVA), with shoot biomass as the covariate (Strand \& Weisner 2001), as follows: $Y_{\text {(morphological responses) }}=$ constant + nutrients + waterlevel fluctuations + nutrients $\times$ water-level fluctuations + shoot biomass. A 2-way ANOVA was used to test the significance of the differences in the total biomass, shoot biomass proportion, branch biomass proportion, and root biomass proportion depending on the sediment nutrient level and amplitude of water-level fluctuation using a Duncan multiple comparison test $(\alpha=0.05)$. All data were analyzed with SPSS 19.0.

\section{RESULTS}

\section{Biomass production}

Sediment nutrient levels and water-level fluctuations had significant effects on biomass production, and the response of biomass production to the water-level fluctuation varied with the sediment nutrient level (Table 1). Plants grown in high-nutrient sediment produced more total biomass than plants grown in low-nutrient sediment. In the highnutrient sediment, an increased accumulation of total plant biomass was observed at a fluctuating amplitude of $\pm 50 \mathrm{~cm}$ compared with the static and $\pm 100 \mathrm{~cm}$ amplitudes. In the low-nutrient sediment, a decrease in total plant biomass was observed as the amplitude of the water level fluctuation increased (Fig. 1a). 
Table 1. Myriophyllum spicatum. F-values of sediment nutrient and water-level fluctuating amplitude for total biomass and root, shoot, branches, and main stem biomass (Duncan multiple comparison test, $\alpha=0.05$ ). All data were transformed using the $\log (x+1)$ function, and all were significant at $\mathrm{p}<0.001$

\begin{tabular}{|lrrrrrr|}
\hline & $\begin{array}{c}\text { Total } \\
\text { biomass }\end{array}$ & Roots & Shoots & Branches & $\begin{array}{c}\text { Main } \\
\text { stem }\end{array}$ & df \\
\hline Sediment nutrients (S) & 381.892 & 412.555 & 96.125 & 194.840 & 58.311 & 1,42 \\
Amplitude (A) & 240.643 & 92.319 & 30.290 & 143.455 & 77.777 & 2,42 \\
S x A & 27.650 & 26.128 & 13.507 & 35.379 & 13.177 & 2,42 \\
\hline
\end{tabular}

\section{Morphological parameters}

Root, shoot, and branch biomass proportions were significantly affected by sediment nutrient level and amplitude of water-level fluctuation, and the interactions between the 2 factors were also significant (Table 1). The root biomass proportion was significantly higher for plants grown in low-nutrient sediment than for those grown in high-nutrient sediment. The root biomass proportion
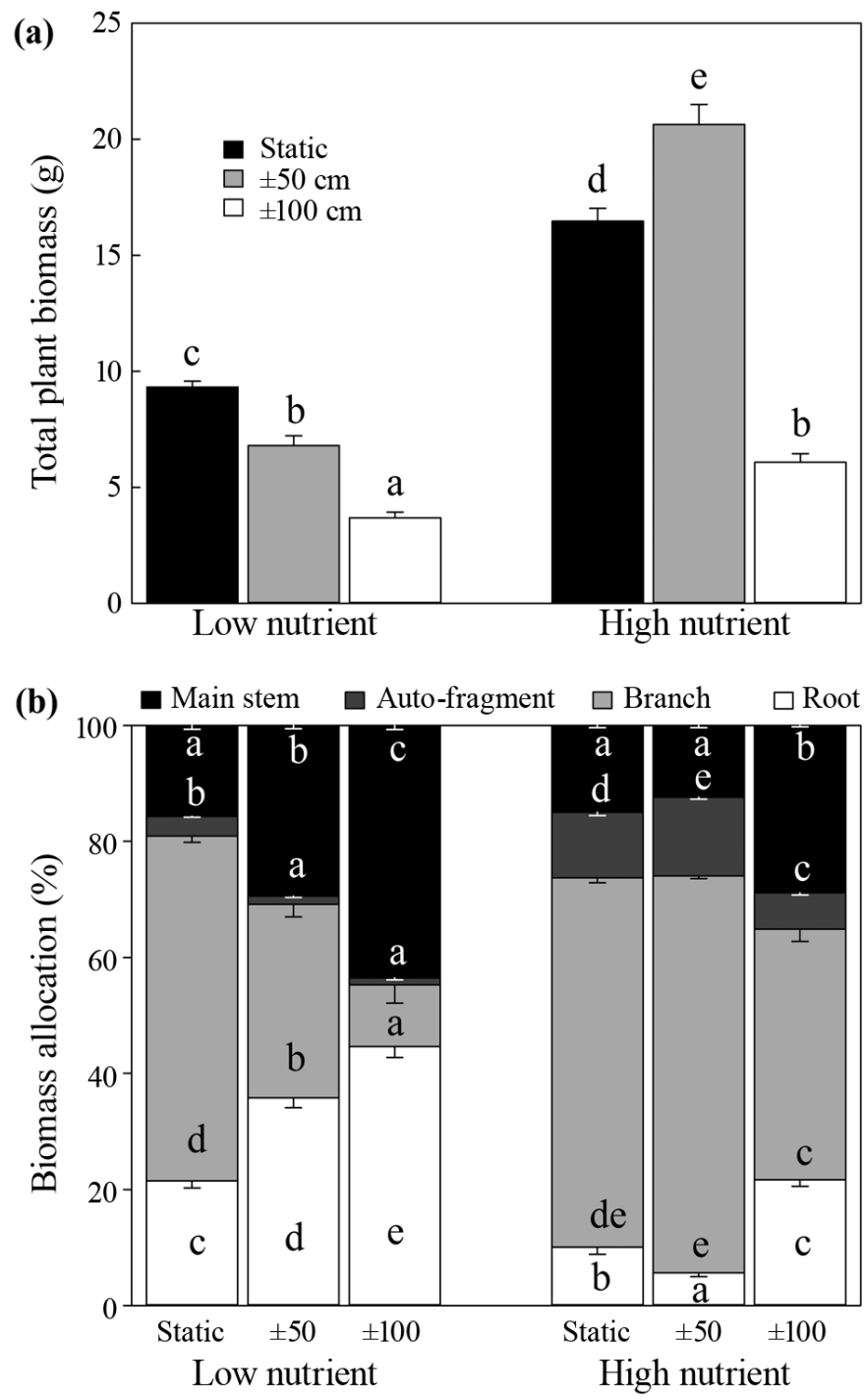

Fig. 1. Myriophyllum spicatum. Mean \pm SE (a) total plant biomass and (b) biomass allocation of $M$. spicatum subjected to 2 sediment nutrient levels (high and low) and 3 amplitudes of water-level fluctuations (static, $\pm 50 \mathrm{~cm}, \pm 100 \mathrm{~cm}$ ). Bars with different letters represent statistically significant differences $(\mathrm{p}<0.05,2$-way ANOVA with Duncan multiple comparison test). All data were transformed using the log $(x+1)$ function was significantly higher with an increasing amplitude of water-level fluctuation (except for the $\pm 50 \mathrm{~cm}$ amplitude in the high-nutrient sediment; Fig. 1b), whereas the opposite trend was observed for the shoot biomass proportion. Plants grown in highnutrient sediment and under relatively stable conditions (static and $\pm 50 \mathrm{~cm}$ amplitude) had a higher branch biomass proportion and lower main stem biomass proportion than plants grown in low-nutrient sediment and under fluctuating conditions $( \pm 100 \mathrm{~cm}$ amplitude; Fig. 1b).

Branch number, branch length, and shoot length were closely correlated with shoot biomass, and these relationships were significantly affected by sediment nutrient level and fluctuating amplitude (Table 2). More and longer branches and taller shoots were observed for plants grown in high-nutrient sediment than those grown in low-nutrient sediment (except for the mean branch length at the static amplitude, Fig. 2b). Significant decreases in branch number and lengths of branches and shoots were observed at $\pm 100 \mathrm{~cm}$ amplitude than at static and $\pm 50 \mathrm{~cm}$ amplitudes (Fig. 2a-c). For plants grown in high-nutrient sediment, more and longer branches and taller shoots were produced in those plants grown at the $\pm 50 \mathrm{~cm}$ amplitude than those grown at the static amplitude. However, except for the shoot length, these differences were not significant for plants grown in low-nutrient sediment (Fig. 2a-c).

\section{Auto-fragment production}

Auto-fragment biomass was also closely correlated with shoot biomass, and auto-fragment production was significantly affected by sediment nutrient level and water-level fluctuation. In addition, auto-fragment production in response to water-level fluctuations also depended on sediment nutrient levels (Table 2). Auto-fragment biomass was significantly higher for plants grown in high-nutrient sediment and under 
Table 2. Myriophyllum spicatum. ANCOVA of branch number, mean branch length, shoot length, and auto-fragment biomass with sediment nutrient and water-level fluctuating amplitude as fixed factors and shoot biomass as covariate. Non-significant interaction terms were eliminated from the analysis to obtain the final model. Data were transformed using the log $(x+1)$ function. ${ }^{*} \mathrm{p}<0.05,{ }^{* *} \mathrm{p}<0.01,{ }^{* * *} \mathrm{p}<0.001$, ns: non-significant

\begin{tabular}{|c|c|c|c|c|c|c|c|c|}
\hline & \multicolumn{2}{|c|}{ Branch number } & \multicolumn{2}{|c|}{ Branch length } & \multicolumn{2}{|c|}{ Shoot length } & \multicolumn{2}{|c|}{ Auto-fragment biomass } \\
\hline & $F$ & $\mathrm{df}$ & $F$ & df & $F$ & $\mathrm{df}$ & $F$ & $\mathrm{df}$ \\
\hline Sediment nutrients (S) & $4.270^{*}$ & 1,41 & $9.076^{* *}$ & 1,36 & $4.270^{*}$ & 1,36 & $58.168^{* * *}$ & 1,39 \\
\hline Amplitude (A) & $3.363^{*}$ & 2,41 & $6.985^{* *}$ & 2,36 & $12.333^{* * *}$ & 2,36 & $11.691^{* * *}$ & 2,39 \\
\hline Shoot biomass (C) & $20.153^{* * *}$ & 1,41 & $10.994^{* *}$ & 1,36 & $63.849^{* * *}$ & 1,36 & $48.478^{* * *}$ & 1,39 \\
\hline $\mathrm{S} \times \mathrm{A}$ & ns & & ns & & ns & & $25.417^{* * *}$ & 2,39 \\
\hline $\mathrm{C} \times \mathrm{A}$ & ns & & $5.918^{* *}$ & 2,36 & $4.581^{*}$ & 2,36 & $10.824^{* * *}$ & 2,39 \\
\hline $\mathrm{C} \times \mathrm{S}$ & ns & & $6.748^{*}$ & 1,36 & $10.860^{* *}$ & 1,36 & $\mathrm{~ns}$ & \\
\hline $\mathrm{C} \times \mathrm{S} \times \mathrm{A}$ & ns & & $5.630^{* *}$ & 2,36 & $4.721^{*}$ & 2,36 & ns & \\
\hline
\end{tabular}

low amplitudes of fluctuation (static and $\pm 50 \mathrm{~cm}$ ) than for plants grown in low-nutrient sediment and under high $( \pm 100 \mathrm{~cm})$ fluctuations (Fig. 2d).

\section{DISCUSSION}

Based on the interactions of the $112 \mathrm{~d}$ water-level fluctuations with different sediment nutrient treatments, most of the morphological responses of Myrio- phyllum spicatum observed in this study can be viewed as adaptive. Our result that an increased sediment nutrient supply (mainly $\mathrm{TN}$ and $\mathrm{TP}$, TN range of $2.2 \sim 2.94 \mathrm{mg} \mathrm{g}^{-1}$ and TP range of $0.09 \sim 0.13 \mathrm{mg}$ $\mathrm{g}^{-1}$ ) increased plant total biomass is consistent with the results of previous studies on this species (Xie \& $\mathrm{Yu} 2011 \mathrm{a}$ ) and other species of submerged macrophytes (Xie et al. 2010, Xie \& Yu 2011b). However, in certain eutrophic water bodies, nutrients do not limit plant growth: the phytoplankton biomass is often
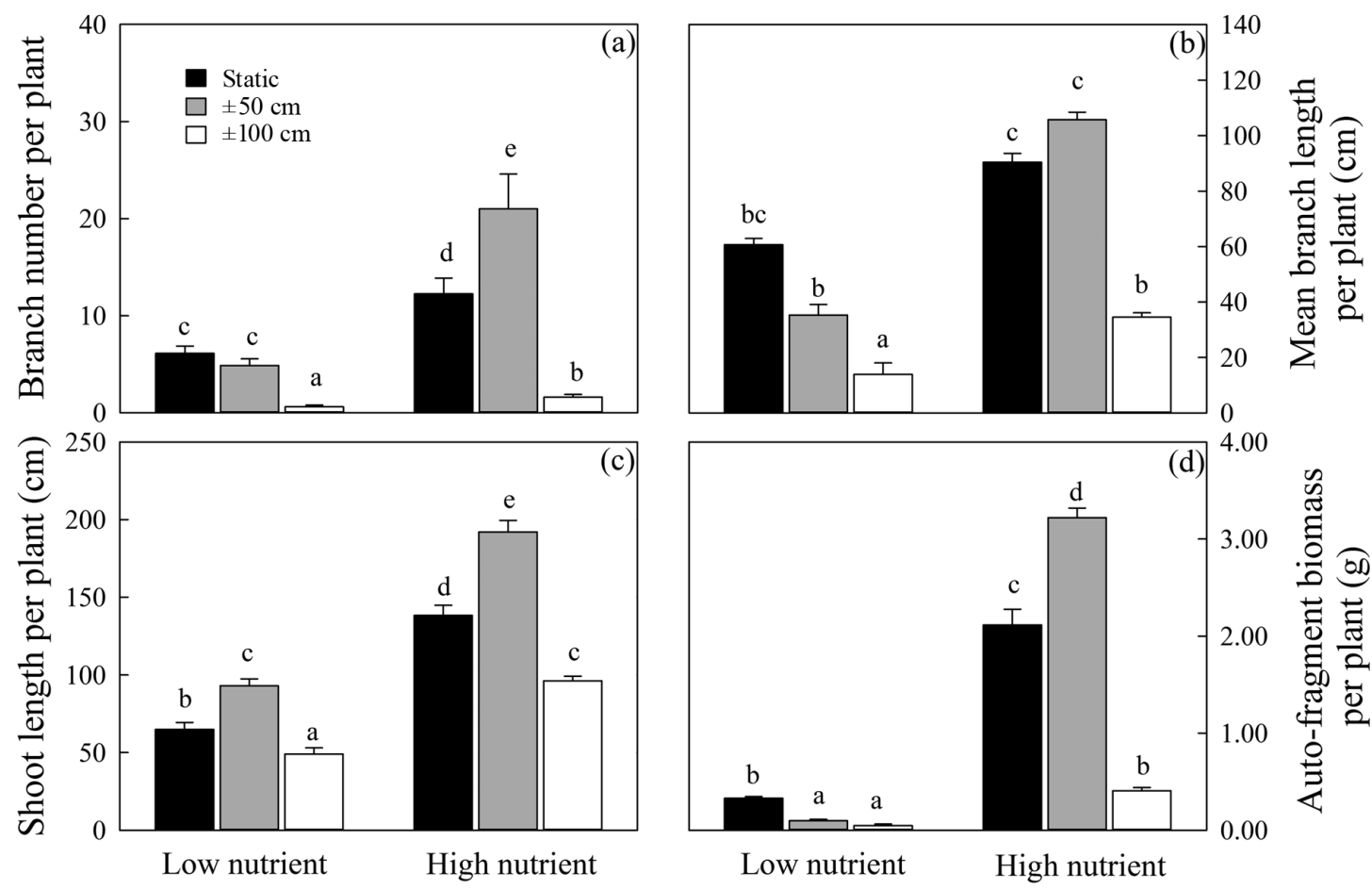

Sediments

Sediments

Fig. 2. Myriophyllum spicatum. Mean $\pm \mathrm{SE}$ (a) branch number, (b) branch length, (c) shoot length, and (d) auto-fragment biomass of M. spicatum subjected to 2 sediment nutrient levels (high and low) and 3 amplitudes of water-level fluctuations (static, $\pm 50 \mathrm{~cm}, \pm 100 \mathrm{~cm})$. Bars with different letters represent statistically significant differences $(\mathrm{p}<0.05,2$-way ANOVA with Duncan multiple comparison test). All data were transformed using the log $(x+1)$ function 
high, whereas the light availability is low, thus affecting the recruitment and growth of all submerged aquatic vegetation (Arthaud et al. 2012, Le BagoussePinguet et al. 2012). The growth of emergent and submerged plants is well known to be enhanced by moderate water levels, due primarily to the abundance of light (Deegan et al. 2007, Yu \& Yu 2009). In our study, $M$. spicatum accumulated a greater total biomass under the $\pm 50 \mathrm{~cm}$ amplitude of water-level fluctuations but did so only in the high-nutrient sediment. This finding is consistent with previous studies of emergent macrophytes that showed that moderate water-level fluctuations promote plant growth under high-nutrient conditions (Xie et al. 2009, Yu \& Yu 2011). However, a higher amplitude of fluctuation $( \pm 100 \mathrm{~cm}$ in our study) may lead to functional damage of the root system, resulting in an increased root biomass allocation and reduced total plant biomass (Xie et al. 2009).

In our study, the growth of Myriophyllum spicatum did not occur equally in the roots and shoots between the different experimental treatments. If sediment nutrients were highly available, a greater production of shoot biomass (to capture more light resources) was expected ('competitive strategy,' Kautsky 1988, Murphy et al. 1990, Grime 2001). In contrast, under low-nutrient conditions, shoot development was constrained because a greater proportion of the biomass was allocated to the root system to increase nutrient acquisition (Xie et al. 2007, Wang et al. 2009). A higher amplitude of water-level fluctuation $( \pm 100 \mathrm{~cm})$ significantly increased the root and main stem biomass proportions. Similar trends were reported by Yang et al. (2004) and Zhang et al. (2012), indicating that $M$. spicatum invests more resources in the roots to avoid being uprooted when growing under moderate water-level fluctuations. In addition, we observed a significant decrease in root biomass in the highnutrient sediment at $\pm 50 \mathrm{~cm}$ amplitude, which indicated that sediment nutrient enrichment and moderate water-level fluctuation $(<60 \mathrm{~cm})$ may interact and facilitate the nutrient acquisition of submerged macrophytes (Xie et al. 2009, Zhang et al. 2012). Nutrient enrichment usually causes the production of shorter main roots and fewer lateral roots in submerged macrophytes (Xie et al. 2005, 2007, Wang et al. 2009), which could benefit the acclimation of plants to deep-water environments by increasing oxygen transport to the root tissues or by reducing the radial oxygen loss and root respiration in these plants.

Because Myriophyllum spicatum is sensitive to stress, sustained stressful conditions (e.g. deep water or low-nutrient sediments) may inhibit growth and limit the lateral spread of this species (Kautsky 1988, Strand \& Weisner 2001). In high-nutrient sediments, $M$. spicatum tended to produce more and longer branches and taller shoots, a pattern that is consistent with that observed for most herbaceous terrestrial plants (Bonser \& Aarssen 2003) and other freshwater macrophytes (Barko \& Smart 1986, Xie et al. 2010, Wersal \& Madsen 2011). Under such conditions, an increased investment in photosynthetic tissue and its enzymatic machinery results in an increased supply of carbohydrates to newly growing branches (i.e. a decreased cost of branch biomass production; Saulnier \& Reekie 1995, Hangelbroek et al. 2003). The allocation of more biomass to shoot structures (i.e. more and longer branches and taller shoots) in high-nutrient sediments may allow M. spicatum to capture more resources (e.g. carbon and light) than in low-nutrient sediments even in deep water. At an amplitude of $\pm 50 \mathrm{~cm}$, the number of branches, mean branch length, and shoot length of $M$. spicatum decreased in the low-nutrient sediment, but the number of branches and shoot length significantly increased in the high-nutrient sediment. This result indicated that an increase in sediment nutrients may facilitate the morphological adaptations of $M$. spicatum in response to moderate water-level fluctuations. M. spicatum has a high light compensation point, a high light saturation level, and a high maximum photosynthetic rate, which can promote a high growth rate for its adaptation to the moderate water-level fluctuations in high-nutrient sediments (Yang et al. 2004). Another possible reason might be enhanced $\mathrm{CO}_{2}$ uptake for net photosynthesis and oxygen uptake for respiration during the fluctuation process (Deegan et al. 2012). However, if the amplitude of the water-level fluctuations changes excessively (i.e. $\pm 100 \mathrm{~cm}$ ), morphological adaptations will occur at any nutrient level, and the plant will maintain a suboptimal morphology due to increasing respiration and anoxia (Strand \& Weisner 2001, Vretare et al. 2001, Deegan et al. 2007, Yu \& Yu 2009). In the natural world, the time scale of water-level fluctuations is generally seasonal, and rapid cyclic water-level fluctuations (i.e. $14 \mathrm{~d}$ cycle in our study) may result in intermittent periods of resource limitation ( $\mathrm{Yu} \& \mathrm{Yu}$ 2009). Therefore, the elongation of plant shoots did not occur at $\pm 100 \mathrm{~cm}$ amplitude in our study. However, different results may be obtained if the time scale of water-level fluctuation is longer (e.g. in different seasons of the year).

The production of auto-fragments was positively correlated with shoot biomass in our study. This result is consistent with the results of previous field 
and experimental studies (Madsen 1997, Smith et al. 2002, Xie \& Yu 2011a). Due to the rapid growth of branches, more auto-fragments were produced in the high-nutrient and relatively stable (static and $\pm 50 \mathrm{~cm}$ amplitude) environments than in the low-nutrient and high-amplitude environments; in the former environment, more lateral branches are produced, thereby increasing the probability of auto-fragment abscission (Xie \& Yu 2011a). In our experiment, plants allocated more resources to growth of the main stem under the low-nutrient level and/or the $\pm 100 \mathrm{~cm}$ amplitude conditions, indicating that adverse conditions force the plants to allocate all available resources to their own growth and/or to halt the production of offspring ramets (Slade \& Hutchings 1987, Caraco \& Kelly 1991).

Wave action appears to be a limiting factor that restricts the growth of canopy-forming submerged species such as Myriophyllum spicatum in environmental management programs to restore submerged macrophyte communities (Madsen et al. 2001, Kemp et al. 2004), although rapid water exchange may prevent subsequent accumulation of epiphytic algae (Strand \& Weisner 2001). In our study, the magnitude of wave action was much smaller than that in nature, although it also may influence the growth of $M$. spicatum (during the rising phase of water-level fluctuation). Longer shoots and more branches were produced by $M$. spicatum at the static and $\pm 50 \mathrm{~cm}$ amplitude in the high-nutrient sediment, potentially leading to an increase in the production of autofragments due to wave action.

\section{CONCLUSIONS}

In this study, Myriophyllum spicatum responded to an increase in sediment nutrients by producing a greater shoot biomass (i.e. more and longer branches) and higher shoot length. Consequently, a higher total plant biomass was attained in the highnutrient sediment. However, the growth of M. spicatum was inhibited by an increased amplitude of water-level fluctuation $( \pm 100 \mathrm{~cm})$ : under this condition, $M$. spicatum allocated more biomass to the roots and main stems and produced fewer and shorter branches. An increase in the sediment nutrient level significantly increased the auto-fragment biomass, whereas higher water-level fluctuations significantly decreased auto-fragment production. These findings suggest that sediment nutrient levels and water-level fluctuations both have strong effects on the growth and reproduction of the submerged macrophyte $M$. spicatum and that high nutrient levels in sediments promote plant growth under conditions of low waterlevel fluctuation. Therefore, to restore submerged macrophyte species within natural water regions, a moderate amplitude of water-level fluctuation is desirable, particularly in high-nutrient habitats.

Acknowledgements. We thank Z. B. Hua for laboratory/field assistance and helpful discussions. We also greatly appreciate the valuable comments from W. F. Vincent and 3 anonymous reviewers on an early version of the manuscript. This research was supported by the National Science Foundation of China (31270741 and 31170417).

\section{LITERATURE CITED}

Aiken SG, Newroth PR, Wile I (1979) The biology of Canadian weeds. 34. Myriophyllum spicatum L. Can J Plant Sci 59:201-215

Ali MM, Soltan MA (2006) Expansion of Myriophyllum spicatum (Eurasian water milfoil) into Lake Nasser, Egypt: invasive capacity and habitat stability. Aquat Bot 84: $239-244$

Arthaud F, Mousset M, Vallod D, Robin J, Wezel A, Bornette G (2012) Effect of light stress from phytoplankton on the relationship between aquatic vegetation and the propagule bank in shallow lakes. Freshw Biol 57:666-675

Barko JW, Smart RM (1983) Effects of organic matter additions to sediment on the growth of aquatic plants. J Ecol 71:161-175

Barko JW, Smart RM (1986) Sediment-related mechanisms of growth limitation in submersed macrophytes. Ecology 67:1328-1340

Barko JW, Adams MS, Clesceri NL (1986) Environmental factors and their consideration in the management of submersed aquatic vegetation: a review. J Aquat Plant Manag 24:1-10

> Bonser SP, Aarssen LW (2003) Allometry and development in herbaceous plants: functional responses of meristem allocation to light and nutrient availability. Am J Bot 90:404-412

Bornette G, Puijalon S (2011) Response of aquatic plants to abiotic factors: a review. Aquat Sci 73:1-14

> Brewer CA, Parker M (1990) Adaptations of macrophytes to life in moving water: upslope limits and mechanical properties of stems. Hydrobiologia 194:133-142

> Buchan LAJ, Padilla DK (2000) Predicting the likelihood of Eurasian watermilfoil presence in lakes, a macrophyte monitoring tool. Ecol Appl 10:1442-1455

Caraco T, Kelly CK (1991) On the adaptive value of physiological integration in clonal plants. Ecology 72:81-93

Chen L, Yuan Y, Lu S, Jin X, Jiao W, Wang J, Cai M (2011) The analysis of pollutant characteristics in surface sediments of the stream inlets and outlets of the main rivers around Taihu Lake. Chin Agric Sci Bull 27: 294-299

Cook CDK (1990) Aquatic plant book. SPB Academic Publishing, Amsterdam

> Coops H, Beklioglu M, Crisman TL (2003) The role of waterlevel fluctuations in shallow lake ecosystems-workshop conclusions. Hydrobiologia 506-509:23-27 
Deegan BM, White SD, Ganf GG (2007) The influence of water level fluctuations on the growth of four emergent macrophyte species. Aquat Bot 86:309-315

Deegan BM, White SD, Ganf GG (2012) Nutrients and water level fluctuations: a study of three aquatic plants. River Res Appl 28:359-368

Gao Y, Yu XM, Liu J, Yang WN, Li DH, Liu YD (2007) Production of adventitious roots and buds on fragments of Myriophyllum spicatum L. Acta Hydrobiol Sin 31:726-730

Grace JB, Wetzel RG (1978) The production biology of Eurasian watermilfoil (Myriophyllum spicatum L.): a review. J Aquat Plant Manag 16:1-11

Grime JP (2001) Plant strategies, vegetation processes, and ecosystem properties. John Wiley \& Sons, Chichester

> Hangelbroek HH, Santamaría L, de Boer T (2003) Local adaptation of the pondweed Potamogeton pectinatus to contrasting substrate types mediated by changes in propagule provisioning. J Ecol 91:1081-1092

Hermans C, Hammond JP, White PJ, Verbruggen N (2006) How do plants respond to nutrient shortage by biomass allocation? Trends Plant Sci 11:610-617

> Huber H, Chen X, Hendriks M, Keijsers D and others (2012) Plasticity as a plastic response: how submergenceinduced leaf elongation in Rumex palustris depends on light and nutrient availability in its early life stage. New Phytol 194:572-582

Jackson MB, Drew M (1984) Effects of flooding on growth and metabolism of herbaceous plants. In: Kozlowski TT (ed) Flooding and plant growth. Academic Press, London, p 47-128

Kautsky L (1988) Life strategies of aquatic soft bottom macrophytes. Oikos 53:126-135

> Kemp MW, Batleson R, Bergstrom P, Carter V and others (2004) Habitat requirements for submerged aquatic vegetation in Chesapeake Bay: water quality, light regime, and physical-chemical factors. Estuaries Coasts 27:363-377

Le Bagousse-Pinguet Y, Liancourt P, Gross N, Straile D (2012) Indirect facilitation promotes macrophyte survival and growth in freshwater ecosystems threatened by eutrophication. J Ecol 100:530-538

Madsen JD (1997) Seasonal biomass and carbohydrate allocation in a southern population of Eurasian watermilfoil. J Aquat Plant Manag 35:15-21

> Madsen TV, Cedergreen N (2002) Sources of nutrients to rooted submerged macrophytes growing in a nutrientrich stream. Freshw Biol 47:283-291

> Madsen JD, Chambers PA, James WF, Koch EW, Westlake DF (2001) The interaction between water movement, sediment dynamics and submersed macrophytes. Hydrobiologia 444:71-84

> Mony C, Thiébaut G, Muller S (2007) Changes in morphological and physiological traits of the freshwater plant Ranunculus peltatus with the phosphorus bioavailability. Plant Ecol 191:109-118

> Müller I, Schmid B, Weiner J (2000) The effect of nutrient availability on biomass allocation patterns in 27 species of herbaceous plants. Perspect Plant Ecol 3:115-127

Murphy KJ, Rørslett B, Springuel I (1990) Strategy analysis of submerged lake macrophyte communities: an international example. Aquat Bot 36:303-323

Pilon J, Santamaría L (2002) Clonal variation in morphological and physiological responses to irradiance and photoperiod for the aquatic angiosperm Potamogeton pectinatus. J Ecol 90:859-870
Puijalon S, Lena JP, Bornette G (2007) Interactive effects of nutrient and mechanical stresses on plant morphology. Ann Bot (Lond) 100:1297-1305

Qiu D, Wu Z, Liu B, Deng J, Fu G, He F (2001) The restoration of aquatic macrophytes for improving water quality in a hypertrophic shallow lake in Hubei Province, China. Ecol Eng 18:147-156

Santamaría L (2002) Why are most aquatic plants widely distributed? Dispersal, clonal growth and small-scale heterogeneity in a stressful environment. Acta Oecol 23: $137-154$

> Saulnier TP, Reekie EG (1995) Effect of reproduction on nitrogen allocation and carbon gain in Oenothera biennis. J Ecol 83:23-29

Slade AJ, Hutchings MJ (1987) The effect of nutrient availability on foraging in the clonal herb Glechoma hederacea. J Ecol 75:95-112

Smith CS, Barko JW (1990) Ecology of Eurasian watermilfoil. J Aquat Plant Manag 28:55-64

Smith DH, Madsen JD, Dickson KL, Beitinger TL (2002) Nutrient effects on autofragmentation of Myriophyllum spicatum. Aquat Bot 74:1-17

> Strand JA, Weisner SEB (2001) Morphological plastic responses to water depth and wave exposure in an aquatic plant (Myriophyllum spicatum). J Ecol 89:166-175

Sugiyama S, Bazzaz FA (1998) Size dependence of reproductive allocation: the influence of resource availability, competition and genetic identity. Funct Ecol 12:280-288

Vretare V, Weisner SEB, Strand JA, Granéli W (2001) Phenotypic plasticity in Phragmites australis as a functional response to water depth. Aquat Bot 69:127-145

- Wang J, Yu D (2007) Influence of sediment fertility on morphological variability of Vallisneria spiralis L. Aquat Bot 87:127-133

> Wang S, Jin X, Jiao L, Wu F (2009) Response in root morphology and nutrient contents of Myriophyllum spicatum to sediment type. Ecol Eng 35:1264-1270

Wersal RM, Madsen JD (2011) Influences of water column nutrient loading on growth characteristics of the invasive aquatic macrophyte Myriophyllum aquaticum (Vell.) Verdc. Hydrobiologia 665:93-105

Xiao K, Yu D, Wang J (2006) Habitat selection in spatially heterogeneous environments: a test of foraging behaviour in the clonal submerged macrophyte Vallisneria spiralis. Freshw Biol 51:1552-1559

Xie D, Yu D (2011a) Size-related auto-fragment production and carbohydrate storage in auto-fragment of Myriophyllum spicatum L. in response to sediment nutrient and plant density. Hydrobiologia 658:221-231

> Xie D, Yu D (2011b) Turion production and nutrient reserves in Potamogeton crispus are influenced by sediment nutrient level. Aquat Biol 14:21-28

> Xie D, Yu D, Yu LF, Liu CH (2010) Asexual propagations of introduced exotic macrophytes Elodea nuttallii, Myriophyllum aquaticum, and $M$. propinquum are improved by nutrient-rich sediments in China. Hydrobiologia 655: $37-47$

> Xie Y, Wen M, Yu D, Li Y (2004) Growth and resource allocation of water hyacinth as affected by gradually increasing nutrient concentrations. Aquat Bot 79:257-266

> Xie Y, An S, Yao X, Xiao K, Zhang C (2005) Short-time response in root morphology of Vallisneria natans to sediment type and water-column nutrient. Aquat Bot 81:85-96

> Xie Y, Luo W, Ren B, Li F (2007) Morphological and physio- 
logical responses to sediment type and light availability in roots of the submerged plant Myriophyllum spicatum. Ann Bot (Lond) 100:1517-1523

Xie Y, Ren B, Li F (2009) Increased nutrient supply facilitates acclimation to high-water level in the marsh plant Deyeuxia angustifolia: the response of root morphology. Aquat Bot 91:1-5

Yang Y, Yu D, Li Y, Xie Y, Geng X (2004) Phenotypic plasticity of two submersed plants in response to flooding. J Freshw Ecol 19:69-76

Editorial responsibility: Warwick Vincent, Sainte-Foy, Quebec, Canada
Yu LF, Yu D (2009) Responses of the threatened aquatic plant Ottelia alismoides to water level fluctuations. Fundam Appl Limnol 174:295-300

Yu LF, Yu D (2011) Differential responses of the floatingleaved aquatic plant Nymphoides peltata to gradual versus rapid increases in water levels. Aquat Bot 94:71-76

Zhang X, Liu X, Ding Q (2012) Morphological responses to water-level fluctuations of two submerged macrophytes, Myriophyllum spicatum and Hydrilla verticillata. J Plant Ecol (in press), doi:10.1093/jpe/rts009

Submitted: May 23, 2012; Accepted: November 5, 2012 Proofs received from author(s): December 5, 2012 